\title{
The Role of the Parasitoid, Aphytis Phoenicis (Hymenoptera: Aphelinidae) in the Biological Control of Parlatoria Date Scale Insect, Parlatoria Blanchardii (Targioni-Tozzetti) Infesting Date Palm Trees in Luxor Governorate, Egypt.
}

\author{
Bakry MMS $^{1 *}$, Salman AMA ${ }^{2}$ and Moussa SFM ${ }^{1}$ \\ ${ }^{1}$ Department of Scale insects and Mealybugs Research, Plant Protection Research Institute, Egypt \\ ${ }^{2}$ Department of Plant Protection, Sohag University, Egypt
}

Submission: November 19, 2016; Published: January 04, 2017

*Corresponding author: Bakry MMS, Department of Scale insects and Mealybugs Research, Plant Protection Research Institute, ARC Dokii, Giza, Egypt, Tel: 201112383122; Email: md.md_sabry@yahoo.com; profdrahmedsalman@yahoo.com

\begin{abstract}
The hymenopterous parasitoid, Aphytis phoenicis (Hymenoptera: Aphelinidae) was found associated with the parlatoria date scale insect, Parlatoria blanchardii (Targioni-Tozzetti) on date palm trees throughout two successive years (2010/2011 and 2011/2012) at Esna district, Luxor Governorate, Egypt. The results showed that half monthly observations of parasitoid had four peaks of seasonal activity per year, which was recorded in mid-October, mid-November, mid-April and mid-June in the first year (2010/2011) and during the mid-October, mid-December, mid-April and mid-June during the $2^{\text {nd }}$ year $(2011 / 2012)$. In addition, the mean highest population of parasitoid, A. phoenicis during the two years was recorded in autumn months, which may due to the environmental conditions were more suitable for the A. phoenicis activity.

The results showed that the relationship between population density of the $P$. blanchardii (Host) and the parasitoid, A. phoenicis activity was good during the two years. Also, the simple regression analysis indicated that the numbers of the parasitoid, A. phoenicis were relatively more correlated with the insect density during autumn, winter, spring and summer and through the year. Also, the percentages of parasitism were ranged between 5.5 to $15.7 \%$ through the first year and ranged between 3.7 to $16.7 \%$ during the second year.
\end{abstract}

The obtained results showed that the percentages of explained variance (E.V.) indicate that all tested variables were responsible for 61.2 and $35.7 \%$ of the population changes of the parasitoid during the $1^{\text {st }}$ and $2^{\text {nd }}$ years of $(2010 / 2011$ and $2011 / 2012)$, respectively.

Keywords: Parasitoid; Aphytis phoenicis; Parlatoria blanchardii; Seasonal activity environmental conditions and date palm trees

\section{Introduction}

Among several pests, infesting date palm trees, parlatoria date scale insect, Parlatoria blanchardii (Targioni-Tozzetti) is considered as pest. Adults and nymphs of this insect feed on leaves sap, sucking great amount of sap which contain macroand micro-elements. At high level of infestation with this scale insect, remarkable damage occurs, resulting in early leaves drop and yield reduction El-Said [1]. Great damages can be done by this scale insect by sucking the plant sap that give low rates of photosynthesis and respiration which leads to curling, yellowing, dropping to leaves. A characteristic symptom of infestation by $P$. blanchardii is the appearance and accumulation of its scales on attacked palm parts El-Said [1], El-Sherif et al. [2], Blumberg [3].

The infested host plant can be so weakened that it dies. Control of these pests by the application of chemical insecticides is a quick and easy step towards the reduction of their population density. However, the use of pesticides is accompanied by many problems, which include the toxic effects on human beings and animals as well as beneficial insects. Pesticides also badly affect soil fauna through their accumulation in the soil. However, the control of armored scale insects in Egypt still relies on the 
use of insecticides, such as organophosphates or mineral oils, especially in the summer during heavy infestations Abd-Rabou [4].

Parasitoids are a major component of natural enemies and integrated pest management programs of scale insects. Parasitoids are insects that feed on the body of another insect or arthropod during the larval stage of the life cycle. The host organism will die as a result. When the parasitoid completes its life cycle, it becomes a free-living insect, no longer dependent on the host. The species of genus Aphytis Howard (Hymenoptera: Aphelinidae) develop exclusively as primary ectoparasitoids of armored scale insects (Hemiptera: Diaspididae) and are usually the most abundant and effective natural enemies of theses serious pests. Several species of Aphytis have been successfully employed in biological control against economically important armored scale insects. The abundance of Aphytis spp. has attracted many authors Mourad \& Zanuncio [5], El-Said [1], AbdRabou \& Hendaway [6], El-Sherif et al. [2].

The objective of this work is to study the seasonal activity and effect of environmental factors on the population density of the parasitoid, A. phoenicis was carried out for two successive years (2010/2011 and 2011/2012) at Esna district, Luxor Governorate.

\section{Material and Methods}

Studying the role of the parasitoid, A.phoenicis (Hymenoptera: Aphelinidae) for controlling the Parlatoria date scale insect, Parlatoria blanchardii infesting date palm trees were carried out at Esna district, Luxor Governorate during the two successive years (2010/2011 and 2011/2012).

\section{The population density of $P$. blanchardii}

Four palms of White variety of almost similar and as uniform as possible in size, age (5 years), shape, height, vegetative growth and received the normal agricultural practices without pruning the fronds and application any chemical control measures before and during the period of investigation, were randomly chosen for sampling which was practiced at half-monthly intervals were selected for carrying out this study. The sample size (12 leaflets) was taken from every palm at a rate of (3 leaflets) from each of the north, east, south and west directions. Regular halfmonthly samples were collected and immediately transferred to laboratory in polyethylene bags for inspection by the aid of stereo-microscope. Number of alive insects on upper and lower surfaces of leaflets on date palm trees were counted and recorded together opposite to each inspected date.

\section{The seasonal abundance of the parasitoid, A. phoenicis}

The associated parasitoid, A. phoenicis of P. blanchardii was examined, identified, counted and recorded was based on halfmonthly counts and depended on the counts of parasitized scale insect with larvae and pupa of $A$. phoenicis for each inspected date (not on the emergency wasps). The specimens of scale insect were put in glass jars and kept under $21-25^{\circ} \mathrm{C}$ and 60 -
$65 \%$ R.H. for securing any emerging parasitoid. Different stages of parasitoid were identified by the specialists in the Biological Control Research Department, Plant Protection Research Institute, Agric. Res. Center, Egypt.

The dissected scales were classified the two following categories:

A. Non-parasitized scale insect.

B. Parasitized scale insect.

In each collected dates, seasonal activity of the parasitoid, A. phoenicis, were studied and the percentage of parasitism was calculated according to the formula of Orphanides [7]:

$$
\% \text { Parasitism }=\frac{\text { No. parasitized scale insects. }}{\text { Total No. parasitized and non-parasitized scale insects. }} \text { X } 100
$$

Concerning, the effect of the main weather factors on the total population of this parasitoid. Necessary meteorological data at Luxor governorate were obtained from the Central Laboratory for Agricultural climate, Agriculture Research Center, Ministry of Agriculture in Giza. The half monthly of tested main weather factors viz. (Max. temp., Min. temp., mean of \% relative humidity and mean of dew point ${ }^{\circ} \mathrm{C}$ ) were worked out.

According to the results of the simple correlation, simple regression coefficient and the partial regression formula which was adopted to find out the simultaneous effects of tested main weather factors on population density of $A$. phoenicis. The partial regression method termed the $\mathrm{C}$-multipliers was adopted according to Fisher [8]. Statistical analysis in the present work was carried out with Computer using MSTATC [9] to determine the preferable time for the parasitoid activity.

\section{Results and Discussion}

\section{Seasonal abundance of the parasitoid, A. phoenicis}

During the investigation, it was observed that parasitoid is played an important role for controlling this pest under field conditions during the two years of (2010/2011 and 2011/2012).

\section{The first year $(2010 / 2011)$}

In the first year of study $(2010 / 2011)$ are represented in Table 1 and illustrated in Figure 1 indicated that the total number of parasitoid started with 9.2 individuals per leaflet of date palm in beginning September and increased gradually to reach the first peak in the mid of October where 19.8 individuals/leaflet were recorded at means of $30.06^{\circ} \mathrm{C}$ and $13^{\circ} \mathrm{C}$ (average of temperature and dew point) and $25.6 \%$ R.H. Then, the parasitoid population decreased slightly during beginning of November.

Again, the population of parasitoid increased to reach the second peak in the mid-November when the individuals reached 18.1 at means of $25^{\circ} \mathrm{C}$ and $11.7^{\circ} \mathrm{C}$ (average of temperature and dew point) and $33.6 \%$ R.H. Thereafter, the population decreased sharply to reach in mid-February. Again, the population increased to reach the third peak in the mid- April when 8.6 individuals/ 
leaflets were recorded at means of $23.4^{\circ} \mathrm{C}$ and $6.6^{\circ} \mathrm{C}$ (average of temperature and dew point) and $25.1 \%$ R.H.

The parasitoid decreased gradually to reach in mid-May. Thereafter, the population increased continuously to reach the fourth peak in mid- June when 10.5 individuals were recorded at the mean field conditions with $33.3^{\circ} \mathrm{C}$ and $10.9^{\circ} \mathrm{C}$ (average of temperature and dew point) and $17.2 \%$ R.H. Moreover, the parasitoid decreased until mid-July. From the beginning of August, the population started increase again (Table 1).

Table 1: Means of half monthly counts of different stages of the parasitoid, A. phoenicis parasited on the scale, P. blanchardii on date palm leaflets, with climatic factors affecting at Esna district, Luxor Governorate during the 2010/2011 year.

\begin{tabular}{|c|c|c|c|c|c|c|c|c|c|c|c|c|}
\hline \multirow{2}{*}{ Season } & \multirow{2}{*}{\multicolumn{2}{|c|}{$\begin{array}{c}\text { Date of } \\
\text { Inspection }\end{array}$}} & \multicolumn{3}{|c|}{ Stages of the Parasitoid } & \multirow{2}{*}{$\begin{array}{c}\text { Non } \\
\text { Parasitized }\end{array}$} & \multirow[t]{2}{*}{ Total } & \multirow{2}{*}{$\begin{array}{c}\% \text { of } \\
\text { Parasitism }\end{array}$} & \multicolumn{4}{|c|}{ Climatic Factors } \\
\hline & & & larvae & pupa & Total & & & & $\begin{array}{c}\text { Max. } \\
\text { temp. } .^{\circ} \mathrm{C}\end{array}$ & $\begin{array}{c}\text { Min. } \\
\text { temp. }{ }^{\circ} \mathrm{C}\end{array}$ & \%R.H. & $\begin{array}{c}\text { Dew } \\
\text { Point }{ }^{\circ} \mathrm{C}\end{array}$ \\
\hline \multirow{6}{*}{ Autumn } & \multirow{2}{*}{ Sept., 2010} & 1 & 7.6 & 1.5 & 9.2 & 67 & 76.2 & 12 & 42.1 & 27.5 & 21.7 & 14.9 \\
\hline & & 15 & 8.5 & 3.6 & 12 & 102.7 & 114.7 & 10.5 & 40.3 & 24.4 & 23.6 & 14.1 \\
\hline & \multirow{2}{*}{ Oct. } & 1 & 12.8 & 3.1 & 15.8 & 139.4 & 155.3 & 10.2 & 39.7 & 23.8 & 25.5 & 14.3 \\
\hline & & 15 & 12.7 & 7.1 & 19.8 & 106.1 & 125.9 & 15.7 & 38.6 & 22.6 & 25.6 & 13 \\
\hline & \multirow{2}{*}{ Nov. } & 1 & 9.1 & 7.6 & 16.8 & 126.5 & 143.3 & 11.7 & 37.6 & 21.1 & 26.9 & 12.4 \\
\hline & & 15 & 11.1 & 7 & 18.1 & 163.7 & 181.8 & 10 & 33 & 17 & 33.6 & 11.7 \\
\hline \multicolumn{3}{|c|}{ Average } & 10.3 & 5 & 15.3 & 117.6 & 132.9 & 11.5 & 38.5 & 22.7 & 26.2 & 13.4 \\
\hline \multirow{6}{*}{ Winter } & \multirow{2}{*}{ Dec. } & 1 & 13.5 & 4.3 & 17.8 & 131.6 & 149.4 & 11.9 & 31.7 & 16.1 & 35.9 & 10.7 \\
\hline & & 15 & 10.2 & 4.6 & 14.8 & 111 & 125.8 & 11.8 & 25.6 & 10.6 & 38.5 & 6.8 \\
\hline & \multirow{2}{*}{ Jan., 2011} & 1 & 7.2 & 2.2 & 9.5 & 93.2 & 102.7 & 9.2 & 25.2 & 8.9 & 39.8 & 5.1 \\
\hline & & 15 & 5.4 & 2.8 & 8.2 & 83.6 & 91.8 & 8.9 & 22.1 & 7.4 & 48.3 & 6.2 \\
\hline & \multirow{2}{*}{ Feb. } & 1 & 4 & 1.1 & 5.1 & 62.7 & 67.8 & 7.5 & 23.3 & 8.2 & 45.9 & 5.8 \\
\hline & & 15 & 2 & 0.4 & 2.3 & 40 & 42.3 & 5.5 & 26.6 & 12.6 & 44.4 & 7.4 \\
\hline \multicolumn{3}{|c|}{ Average } & 7.1 & 2.6 & 9.6 & 87 & 96.6 & 10 & 25.8 & 10.6 & 42.1 & 7 \\
\hline \multirow{6}{*}{ Spring } & \multirow{2}{*}{ Mar. } & 1 & 2.9 & 0.3 & 3.2 & 48 & 51.3 & 6.3 & 25.9 & 12.1 & 41.4 & 4.6 \\
\hline & & 15 & 3.2 & 0.9 & 4.1 & 63.7 & 67.9 & 6.1 & 27.2 & 11.4 & 30.1 & 4.4 \\
\hline & \multirow{2}{*}{ April } & 1 & 4.9 & 2.4 & 7.4 & 75.5 & 82.8 & 8.9 & 28.8 & 15.3 & 32.4 & 5.2 \\
\hline & & 15 & 5.7 & 3 & 8.6 & 87 & 95.6 & 9 & 30.3 & 16.4 & 25.1 & 6.6 \\
\hline & \multirow{2}{*}{ May } & 1 & 5.1 & 1.4 & 6.5 & 64.2 & 70.7 & 9.2 & 34.1 & 18.1 & 19.2 & 6.4 \\
\hline & & 15 & 3.6 & 1.6 & 5.2 & 48.2 & 53.4 & 9.7 & 35.9 & 20.5 & 18.1 & 7.4 \\
\hline \multicolumn{3}{|c|}{ Average } & 4.2 & 1.6 & 5.8 & 64.4 & 70.3 & 8.3 & 30.4 & 15.6 & 27.7 & 5.8 \\
\hline
\end{tabular}




\begin{tabular}{|c|c|c|c|c|c|c|c|c|c|c|c|c|}
\hline \multirow{6}{*}{ Summer } & \multirow{2}{*}{ June } & 1 & 4.7 & 0.6 & 5.4 & 83.5 & 88.8 & 6 & 38.4 & 22.1 & 18.3 & 9.4 \\
\hline & & 15 & 6.2 & 4.3 & 10.5 & 113.2 & 123.7 & 8.5 & 41.1 & 25.6 & 17.2 & 10.9 \\
\hline & \multirow{2}{*}{ July } & 1 & 6.3 & 1.7 & 8 & 93.6 & 101.5 & 7.8 & 39.3 & 24.5 & 19.6 & 11.6 \\
\hline & & 15 & 3.5 & 3.7 & 7.2 & 74.8 & 82 & 8.8 & 41.7 & 25.3 & 19.8 & 12.8 \\
\hline & \multirow{2}{*}{ Aug. } & 1 & 3.6 & 4.2 & 7.8 & 67.2 & 75 & 10.4 & 41.8 & 28.2 & 20.1 & 13.6 \\
\hline & & 15 & 4.1 & 5.3 & 9.4 & 71 & 80.4 & 11.7 & 40.9 & 27.7 & 20.9 & 14.1 \\
\hline \multicolumn{3}{|c|}{ Average } & 4.7 & 3.3 & 8 & 83.9 & 91.9 & 8.8 & 40.5 & 25.6 & 19.3 & 12.1 \\
\hline \multicolumn{3}{|c|}{ Total } & 158 & 74.7 & 232.7 & 2117.5 & 2350.2 & 9.9 & & & & \\
\hline \multicolumn{3}{|c|}{ mean } & 6.6 & 3.1 & 9.7 & 88.2 & 97.9 & & & & & \\
\hline
\end{tabular}
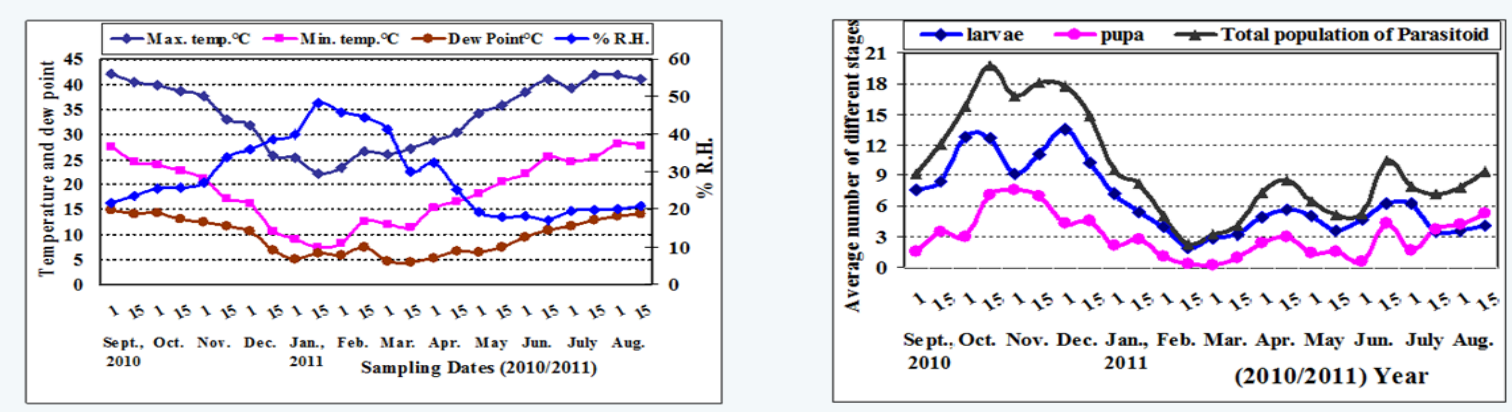

Figure 1: Means of half monthly counts of different stages of the parasitoid, Aphytis phoenicis parasited on the scale, P. blanchardii on date palm leaflets, with climatic factors affecting at Esna district, Luxor Governorate during the 2010/2011 year.

\section{The second year $(2011 / 2012)$}

Table 2: Means of half monthly counts of different stages of the parasitoid, A. phoenicis parasited on the scale, P. blanchardii on date palm leaflets, with climatic factors affecting at Esna district, Luxor Governorate during the 2011/2012 year.

\begin{tabular}{|c|c|c|c|c|c|c|c|c|c|c|c|c|}
\hline \multirow[b]{2}{*}{ Season } & \multirow{2}{*}{\multicolumn{2}{|c|}{ Date of Inspection }} & \multicolumn{3}{|c|}{ Stages of ohe Parasitoid } & \multirow{2}{*}{$\begin{array}{c}\text { Non } \\
\text { Parasitized }\end{array}$} & \multirow[b]{2}{*}{ Total } & \multirow[b]{2}{*}{$\begin{array}{c}\% \text { of } \\
\text { Parasitism }\end{array}$} & \multicolumn{4}{|c|}{ Climatic Factors } \\
\hline & & & larvae & pupa & Total & & & & Max. & Min. & \%R.H. & $\begin{array}{l}\text { Dew } \\
\text { Point }\end{array}$ \\
\hline \multirow{6}{*}{ Autumn } & \multirow{2}{*}{$\begin{array}{l}\text { Sept., } \\
2011\end{array}$} & 1 & 9.3 & 1.9 & 11.1 & 91.9 & 103.1 & 10.8 & 39.8 & 24.8 & 20.9 & 12.8 \\
\hline & & 15 & 11.4 & 2.7 & 14.1 & 110.3 & 124.4 & 11.3 & 38.5 & 24.6 & 24.6 & 13.6 \\
\hline & \multirow{2}{*}{ Oct. } & 1 & 12.4 & 4.8 & 17.25 & 119.8 & 137.1 & 12.6 & 37.7 & 22.5 & 26.3 & 13.3 \\
\hline & & 15 & 13.1 & 4.2 & 17.3 & 125.1 & 142.4 & 12.1 & 36.4 & 20.6 & 26.7 & 12.2 \\
\hline & \multirow{2}{*}{ Nov. } & 1 & 6.3 & 3.5 & 9.8 & 78.8 & 88.6 & 11.1 & 33 & 18.4 & 33.7 & 12.1 \\
\hline & & 15 & 4.3 & 3.6 & 7.9 & 63.4 & 71.3 & 11.1 & 29.1 & 12.7 & 34 & 7.7 \\
\hline \multicolumn{3}{|c|}{ Average } & 9.5 & 3.5 & 12.9 & 98.2 & 111.1 & 11.5 & 35.7 & 20.6 & 27.7 & 12 \\
\hline
\end{tabular}


Agricultural Research \& Technology: Open Access Journal

\begin{tabular}{|c|c|c|c|c|c|c|c|c|c|c|c|c|}
\hline \multirow{6}{*}{ Winter } & \multirow{2}{*}{ Dec. } & 1 & 12.1 & 3.9 & 16 & 79.5 & 95.5 & 16.7 & 24.1 & 10.3 & 40.6 & 6.6 \\
\hline & & 15 & 16.2 & 7.3 & 23.5 & 136 & 159.5 & 14.7 & 24.6 & 7.3 & 43 & 5.8 \\
\hline & \multirow{2}{*}{$\begin{array}{l}\text { Jan., } \\
2012\end{array}$} & 1 & 7.4 & 2.3 & 9.7 & 126.9 & 136.6 & 7.1 & 23.5 & 7.7 & 45.6 & 5.9 \\
\hline & & 15 & 3.7 & 1.9 & 5.5 & 99.5 & 105 & 5.3 & 19.7 & 5.4 & 44.6 & 3.3 \\
\hline & \multirow{2}{*}{ Feb. } & 1 & 2.6 & 0.7 & 3.3 & 62.7 & 66.1 & 5 & 21.8 & 6.1 & 42.4 & 3.6 \\
\hline & & 15 & 1.7 & 0.3 & 2 & 52 & 54 & 3.7 & 24.8 & 9.3 & 29.6 & 2.6 \\
\hline \multicolumn{3}{|c|}{ Average } & 7.3 & 2.7 & 10 & 92.8 & 102.8 & 8.8 & 23.1 & 7.7 & 41 & 4.6 \\
\hline \multirow{6}{*}{ Spring } & \multirow{2}{*}{ Mar. } & 1 & 2.4 & 0.2 & 2.6 & 37.6 & 40.3 & 6.6 & 25.3 & 9.9 & 33.4 & 4.8 \\
\hline & & 15 & 3 & 0.8 & 3.8 & 41.4 & 45.2 & 8.4 & 27.1 & 11 & 21.1 & 0.6 \\
\hline & \multirow{2}{*}{ April } & 1 & 5.2 & 2.5 & 7.8 & 77.6 & 85.4 & 9.1 & 27.5 & 11.3 & 18.8 & -0.2 \\
\hline & & 15 & 4.1 & 4.6 & 8.8 & 89.7 & 98.5 & 8.9 & 34.9 & 17.9 & 11.6 & 0.7 \\
\hline & \multirow{2}{*}{ May } & 1 & 4.8 & 1.3 & 6.1 & 88.1 & 94.2 & 6.5 & 36.4 & 18.4 & 8.5 & -1.4 \\
\hline & & 15 & 2.7 & 1.2 & 3.8 & 76.3 & 80.2 & 4.8 & 37.8 & 21 & 9.1 & 1.6 \\
\hline \multicolumn{3}{|c|}{ Average } & 3.7 & 1.8 & 5.5 & 68.5 & 74 & 7.4 & 31.5 & 14.9 & 17.1 & 1 \\
\hline \multirow{6}{*}{ Summer } & \multirow{2}{*}{ June } & 1 & 5.7 & 0.8 & 6.4 & 71 & 77.5 & 8.3 & 39.9 & 24.5 & 9.8 & 4.3 \\
\hline & & 15 & 7 & 4.8 & 11.8 & 116.2 & 127.9 & 9.22 & 41.4 & 24.5 & 14.1 & 8.4 \\
\hline & \multirow{2}{*}{ July } & 1 & 8 & 2.1 & 10.1 & 99.9 & 110.1 & 9.18 & 42.1 & 27.1 & 18.8 & 13.7 \\
\hline & & 15 & 4.3 & 4.5 & 8.8 & 90 & 98.8 & 8.9 & 40.7 & 26.1 & 20.9 & 14.3 \\
\hline & \multirow{2}{*}{ Aug. } & 1 & 3.5 & 4.1 & 7.5 & 82 & 89.5 & 8.4 & 42.6 & 27.2 & 21.6 & 15.4 \\
\hline & & 15 & 4.2 & 5.5 & 9.7 & 85.9 & 95.5 & 10.1 & 41.6 & 26.4 & 21.1 & 14.3 \\
\hline \multicolumn{3}{|c|}{ Average } & 5.4 & 3.6 & 9 & 90.8 & 99.9 & 9 & 41.4 & 26 & 17.7 & 11.7 \\
\hline \multicolumn{3}{|c|}{ Total } & 155.2 & 69.6 & 224.8 & 2101.9 & 2326.7 & 9.7 & & & & \\
\hline \multicolumn{3}{|c|}{ mean } & 6.5 & 2.9 & 9.4 & 12.3 & 96.9 & 9.7 & & & & \\
\hline
\end{tabular}
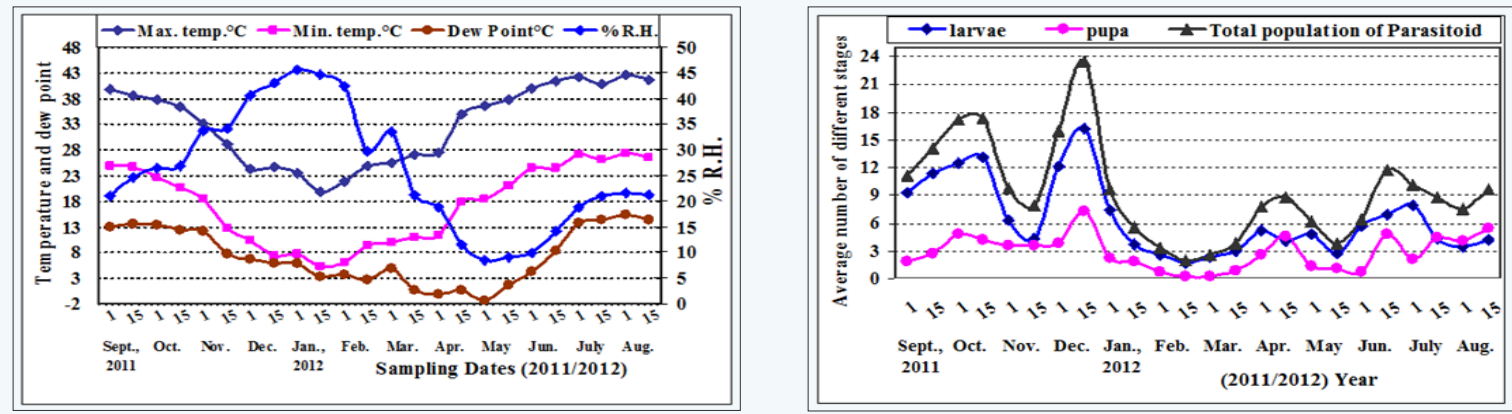

Figure 2: Means of half monthly counts of different stages of the parasitoid, $A$. phoenicis parasited on the scale, $P$. blanchardii on date palm leaflets, with climatic factors affecting at Esna district, Luxor Governorate during the 2011/2012 year.

During the second year of $(2011 / 2012)$ as shown in (Table 2) and illustrated in (Figure2), it wascleared that the total population of $A$. phoenicis were four peaks of activity were recorded in MidOctober, Mid-December, Mid-April and Mid-June when 17.3, 23.5, 8.8 and 11.8 individuals per leaflets, respectively. Also, the total population of parasitoid, A. phoenicis during the first year was higher than in the second one, which may due to the influence of favorable factors (such as environmental conditions, ...etc.). In addition, the mean highest population of parasitoid, A. phoenicis during the two years of study were recorded in autumn months, thus due to the environmental conditions were more suitable for the A. phoenicis activity. Abdel-Kareim \& Awadalla [10] reported that the parasitoids showed the highest abundance in autumn and the lowest in winter months. 


\section{Density dependent-relationship}
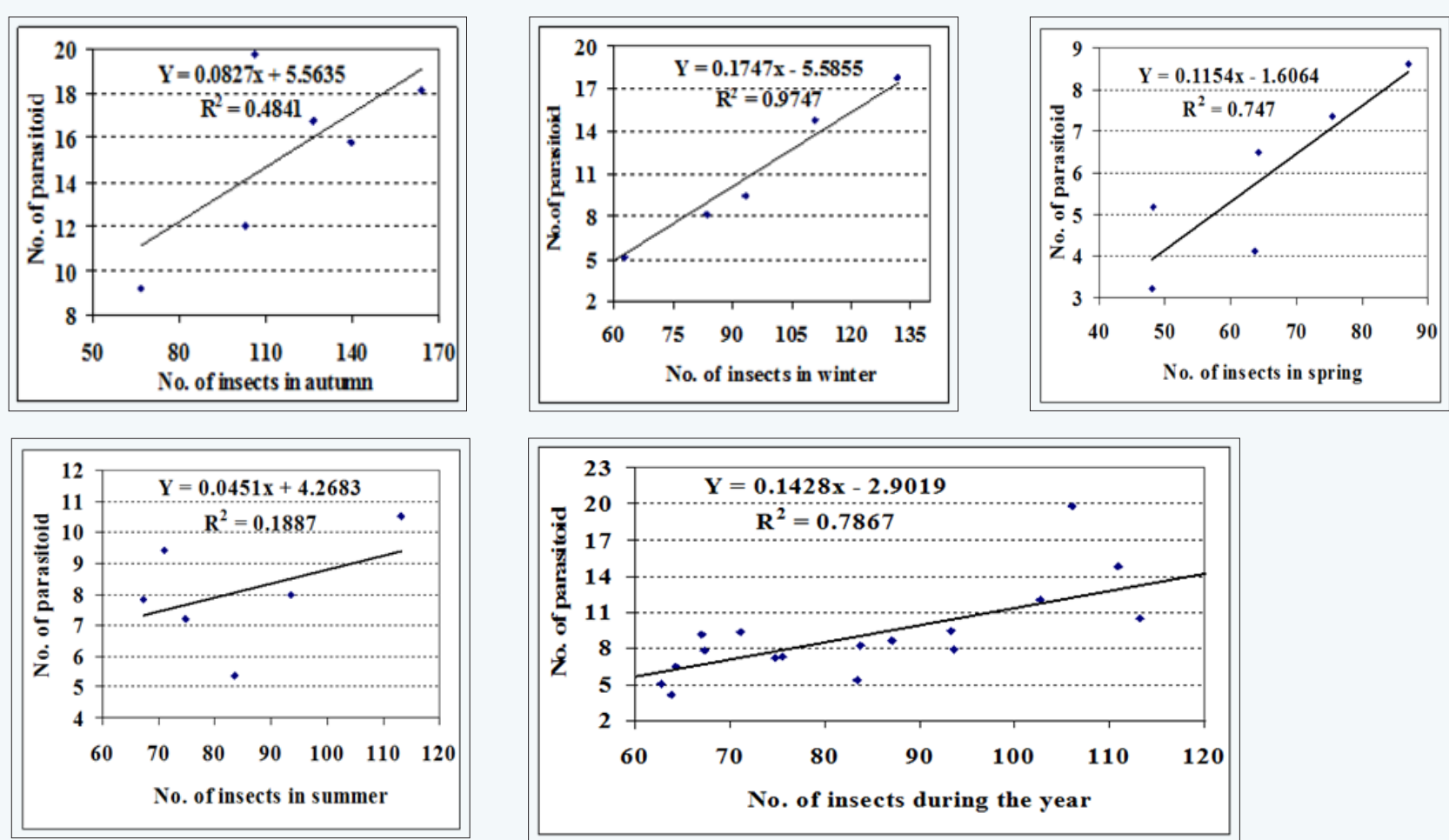

Figure 3: Synchronization between P. blanchardii population (living scales) and the parasitoid, $A$. phoenicis population on date palm trees during the different seasons of the year, 2010/2011.
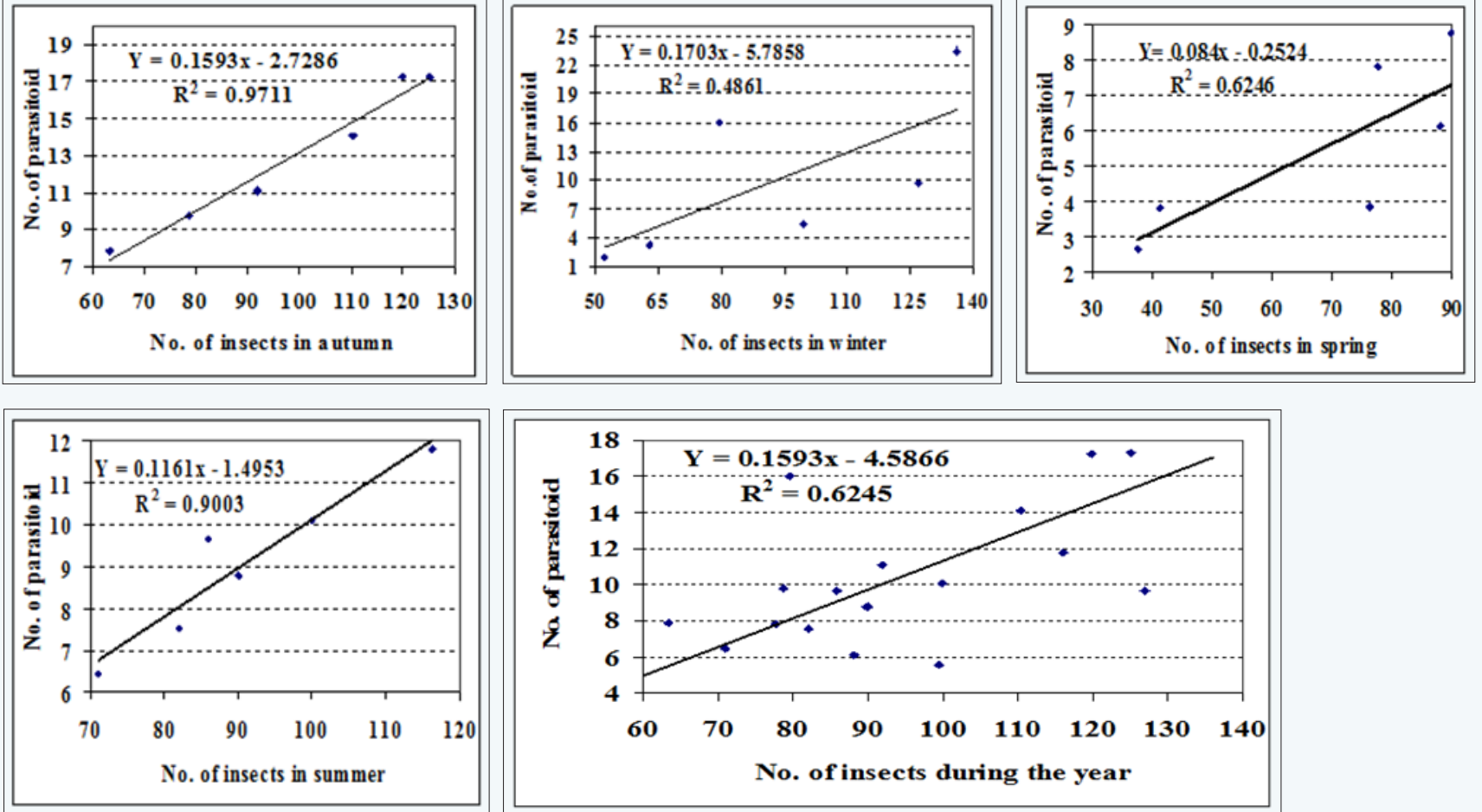

Figure 4: Synchronization between P. blanchardii population (living scales) and the parasitoid, A. phoenicis population on date palm trees during the different seasons of the year, 2011/2012. 
The density- dependent response was determined for A. phoenicis during the different seasons (autumn, winter, spring and summer) through the two years of $(2010 / 2011$ and 2011/2012) (Figure 3 \& 4).

By plotting numbers of the parasitoid, A. phoenicis against the population density of the P. blanchardii, the simple regression analysis indicated that the numbers of the parasitoid, A. phoenicis (NP) were relatively more correlated with the insect density (ID) during autumn, winter, spring and summer (Figure $3 \& 4)$.

The density relationship could be represented by the following submodels:

In the first year (2010/2011):

$\mathrm{NP}=5.56+0.083$ ID In autumn; NP $=-5.59+0.175$ ID In winter

$\mathrm{NP}=-1.61+0.115$ ID In spring; $\mathrm{NP}=4.27+0.045$ ID In summer

$\mathrm{NP}=-2.90+0.143$ ID In the whole year.

In the second year (2011/2012):

$\mathrm{NP}=-2.73+0.159$ ID In autumn; NP $=-5.79+0.170$ ID In winter

$\mathrm{NP}=-0.25+0.084$ ID In spring; $\mathrm{NP}=-1.50+0.116$ ID In summer

$\mathrm{NP}=-4.59+0.159$ ID In the whole year.

The obtained results revealed that, significant increase in the numbers of parasitoid, A. phoenicis was shown in the different seasons and during the year with increasing the population density of insect by $(0.083,0.175,0.115,0.045$ and 0.143$)$ and $(0.159,0.170,0.084,0.116$ and 0.159$)$ individuals per leaflet in the autumn, winter, spring, summer seasons and during the whole year for the two successive years, respectively, Figure $3 \& 4$. The above mentioned results are in agreement with those obtained by Abdel-Kareim \& Awadalla [10] came to similar results.

This parasitoid is dominant and attacks the second instar nymphs and adults of $P$. blanchardii except the first instar nymphs. During the examination to observe the larvae of the parasitoid have been protected within the pest body, most of them can't be able to complete the life cycle to pupal stage. So, we can attribute this observation either to the death of the host insect, or to the physiological reaction of this host against the parasitic larvae.

\section{Percentage of parasitism}

The first year (2010/2011): Data given in Table 1 and illustrated in Figure 5, cleared that in the four peaks of activity were recorded the two years of investigation. In the first year (2010/2011), were took place in mid - October (15.72\%), beginning of December (11.91\%), mid-May (9.7\%) and mid-June $(8.5 \%)$.

The second year (2011/2012): During, the second year of study (2011/2012) as recorded in Table 2 and Figure 5, it was found that the highest percentage of parasitism were recorded in beginning of October (12.6\%), beginning of December $(16.7 \%)$, beginning of April (9.1\%) and mid-June (9.22\%). Also, the highest rate of parasitism (16.7\%) occurred when scale population was smallest (79.5 individuals per leaflets) in beginning of December.
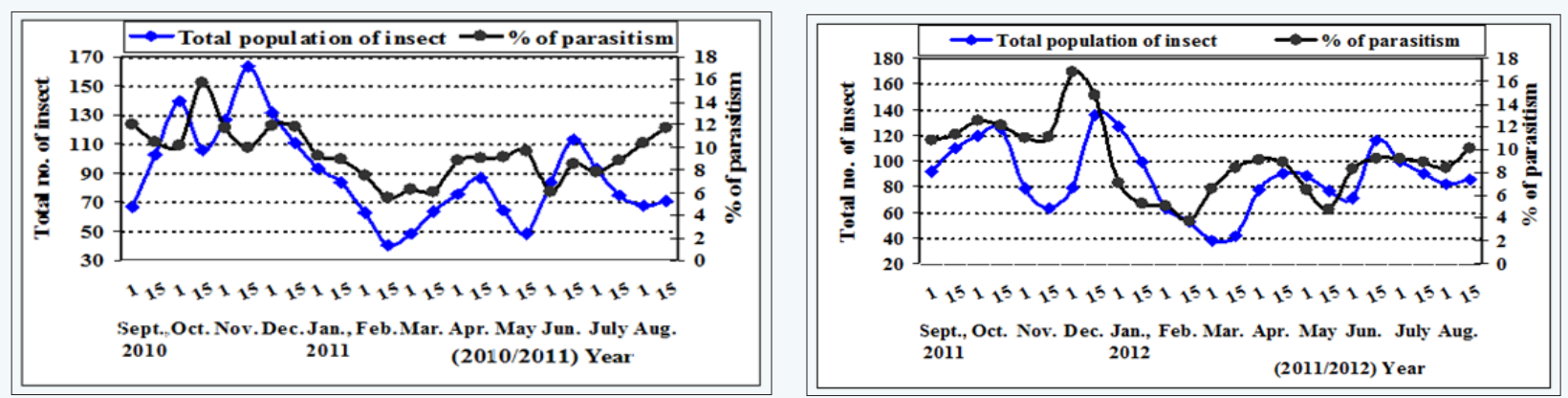

Figure 5: Seasonal abundance of $P$. blanchardii and the percentage of parasitism on date palm leaflets during the two years of (2010/2011 and 2011/2012).

On the other hand, considering parasitism percentage during the four seasons of year (autumn, winter, spring and summer) it could be noticed that in first year of parasitism was higher in autumn followed by winter in comparison with spring and summer, Table 1 . While, the second year was higher in autumn followed by summer in comparison with winter and spring, Table 2.
Generally, the rates of parasitism were ranged between 5.5 to $15.7 \%$ through the first year and ranged between 3.7 to $16.7 \%$ during the second year. The differences in our results may be due to the differences in the prevailing climatic elements. These results were coincided with those obtained by Gomaa [11] in Giza, Egypt, recorded that Aphytis sp. has three generations per year during October, April and August. Saad [12] in Giza, Egypt, observed that Aphytis sp. and Aspidiotiphagus lounsburyi 
(Hymenoptera: Aphelinidae) were parasited on P. blanchardii. Parasitism was mostly occurred during March, April, June, August and October. Eraki [13] in Egypt mentioned that the $P$. blanchardii is controlled by natural enemies, such as A. phoenicis. The parasitoid, A. phoenicis on this scale and showed with extensive numbers through each of June, November, January and March.

El-Said [1] in North Sinai, Egypt, recorded that the rate of parasitism by A. phoenicis ranged $21.4-33.6 \%$ in spring, 21.3 $36.7 \%$ in summer, $35.3-46.8 \%$ in autumn and $18.5-39.1 \%$ in winter. Abd-Rabou and Headway [4] in Ismailia, Egypt, reported that the maximum parasitism rates of $A$. phoenicis on $P$. blanchardii on date palm trees was $20.4 \%$ during August, with an average rates $12.7 \%$. El-Sherif et al. [2] in North Sinai,

Table 3: Effect of both temperature, relative humidity and dew point on total number of the parasitoid, A. phoenicis at Esna district, Luxor Governorate during the two years of (2010/2011 and 2011/2012).

\begin{tabular}{|c|c|c|c|c|c|c|c|c|c|c|c|c|c|}
\hline \multirow{2}{*}{ Year } & \multirow{2}{*}{$\begin{array}{l}\text { Tested } \\
\text { Factors }\end{array}$} & \multicolumn{4}{|c|}{$\begin{array}{l}\text { Simple Correlation and } \\
\text { Regression Values }\end{array}$} & \multicolumn{3}{|c|}{$\begin{array}{c}\text { Partial Regression } \\
\text { Values }\end{array}$} & \multirow[t]{2}{*}{$\begin{array}{c}\text { Individual } \\
\text { Role \% }\end{array}$} & \multicolumn{4}{|c|}{ Analysis Variance } \\
\hline & & $\mathbf{r}$ & b & S.E & $\mathbf{t}$ & P.reg & S.E & $\mathbf{t}$ & & F values & MR & $\mathbf{R 2}$ & E.V. \% \\
\hline \multirow{4}{*}{$2 / 11 / 2010$} & $\begin{array}{l}\text { Max. } \\
\text { tem. }{ }^{\circ} \mathrm{C}\end{array}$ & 0.27 & 0.2 & 0.15 & 1.31 & -0.3 & 1.08 & -0.27 & 0.15 & \multirow{4}{*}{$7.49^{* *}$} & \multirow{4}{*}{0.78} & \multirow{4}{*}{0.61} & \multirow{4}{*}{61.2} \\
\hline & $\begin{array}{l}\text { Min. } \\
\text { tem. }{ }^{\circ} \mathrm{C}\end{array}$ & 0.21 & 0.16 & 0.16 & 1.02 & $1.67 *$ & 0.71 & $-2.35^{*}$ & 11.3 & & & & \\
\hline & R.H.\% & -0.07 & -0.03 & 0.11 & 0.31 & -0.58 & 0.32 & -1.8 & 6.63 & & & & \\
\hline & $\begin{array}{l}\text { Dew } \\
\text { Point }{ }^{\circ} \mathrm{C}\end{array}$ & $0.52^{* *}$ & $0.73^{* *}$ & 0.25 & $2.89 * *$ & $2.94^{*}$ & 0.82 & $3.57^{*}$ & 26.1 & & & & \\
\hline \multirow{4}{*}{$2011 / 2012$} & $\begin{array}{l}\text { Max. } \\
\text { tem. }{ }^{\circ} \mathrm{C}\end{array}$ & 0.16 & 0.11 & 0.15 & 0.77 & 2.16 & 1.2 & 1.8 & 10.95 & \multirow{4}{*}{2.63} & \multirow{4}{*}{0.6} & \multirow{4}{*}{0.36} & \multirow{4}{*}{35.7} \\
\hline & $\begin{array}{l}\text { Min. } \\
\text { tem. }{ }^{\circ} \mathrm{C}\end{array}$ & 0.17 & 0.12 & 0.15 & 0.81 & -1.71 & 1.43 & -1.19 & 4.79 & & & & \\
\hline & R.H.\% & 0.21 & 0.1 & 0.1 & 1.02 & 0.37 & 0.44 & 0.84 & 2.44 & & & & \\
\hline & $\begin{array}{c}\text { Dew } \\
\text { Point }{ }^{\circ} \mathrm{C}\end{array}$ & $0.46^{*}$ & $0.44^{*}$ & 0.18 & $2.41^{*}$ & 0.21 & 0.88 & 0.24 & 0.18 & & & & \\
\hline
\end{tabular}

Effect of mean maximum temperature: The results of statistical analysis of simple correlation (Table 3) showed a positive and insignificant correlation between the maximum temperature and total population of $A$. phoenicis in the first and second years, $r$ value was $(+0.27$ and +0.16$)$, respectively. The unit effect regression coefficient (b), indicates that an increase of $1^{\circ} \mathrm{C}$ in the maximum temperature increased the population of parasitoid by 0.20 and 0.11 individuals per leaflets for the $1^{\text {st }}$ and
Egypt, reported that an unidentified Hymenopterous parasitoid (Aphytis sp.) parasitized up on $18.5-46.8 \%$ of nymphs and adult of $P$. blanchardii populations.

\section{Effect of the main climatic factors on the population density of parasitoid, $A$. phoenicis:}

The single and combined effects of the main climatic factors, (means of maximum temperature, minimum temperature, relative humidity and dew point) on the total population of this parasitoid, A. phoenicis were studied. The results (Table 3), summarized the simple correlation and regression values, as well as the partial regression values with their significance levels (P.) and the percentage of explained variance for the combined effect of these climatic factors. $2^{\text {nd }}$ years, respectively. As well as, the partial regression values (P.reg) emphasized an insignificant negative relation (-0.30) and $t$ value was $(-0.27)$ for the first year, while it was insignificant positive $(+2.16)$ and $t$ value was $(+1.80)$ for the second one, when the mean maximum temperature become around its mean. The obtained results revealed that, mean maximum temperature around the optimum range of total population of $A$. phoenicis activity during the $1^{\text {st }}$ year and within the optimum range in the 
$2^{\text {nd }}$ year. Most of the changes in the population of parasitoid are due to maximum temperature was the most effective variable in population change $(10.95 \%)$ during the second year.

Effect of mean minimum temperature: Concerning the data in Table 3, revealed an insignificant and positive correlation for the $1^{\text {st }}$ and $2^{\text {nd }}$ years of study, respectively ( $r$ value was +0.21 and +0.17 ), respectively. In the same table, the calculated regression coefficient for the unit effect of this factor indicated that for every $1^{\circ} \mathrm{C}$ increase in the mean minimum temperature, population density of parasitoid increased by 0.16 and 0.12 individuals per leaflets for $1^{\text {st }}$ and $2^{\text {nd }}$ years, respectively (Table 3 ). The precise effect of the mean minimum temperature on the population of parasitoid, showed that it was significant negative (P.reg value) was -1.67 and $t$ value was $(-2.35)$ for the $1^{\text {st }}$ year. However, insignificant negative $(-1.71)$ and t value was $(-1.19)$ during the second one, when the mean minimum temperature become around its mean. The obtained results revealed that, mean minimum temperature above the optimum range of total population of $A$. phoenicis activity during the $1^{\text {st }}$ year and around the optimum range in the $2^{\text {nd }}$ year. Also, the minimum temperature was the most effective variable in population changes of the parasitoid (11.30\%) during the first year.

Effect of mean relative humidity: The effect of mean relative humidity on parasitoid activity was insignificant negative for $1^{\text {st }}$ year ( $r$ was -0.07), while was insignificant positive for the $2^{\text {nd }}$ year $(+0.21)$. The unit effect (regression coefficient) indicates that an increase of $1 \%$ R.H., decreased the population density of A. phoenicis by 0.03 and increased by 0.10 individuals per leaflet for $1^{\text {st }}$ and $2^{\text {nd }}$ years of study, respectively (Table 3 ). As well as, the partial regression analysis for the effect of mean relative humidity on the population of parasitoid revealed that, it was insignificant negative (P.reg value was -0.58 ) and ( $t$ value was $-1.80)$ for the $1^{\text {st }}$ year. However, insignificant positive $(+0.37)$ and $t$ value was $(+0.84)$ during the second one, when the mean relative humidity become around its mean. The obtained results revealed that, mean relative humidity around the optimum range of total population of $A$. phoenicis activity in the $1^{\text {st }}$ year and within the optimum range during the $2^{\text {nd }}$ year.

Effect of mean dew point: Concerning the data in Table 3 showed that the simple correlation ( $\mathrm{r}$ ) between the mean dew point and the population density of parasitoid, A. phoenicis was highly significantly positive $(+0.52)$ and significantly positive $(+0.46)$ for the first and second years, respectively.

As well as, the calculated regression coefficient (b) for the effect of this factor indicated that every $1^{\circ} \mathrm{C}$ increase in the mean maximum temperature increased the population by 0.73 and 0.44 individuals per respectively. The exactly relationship between this climatic factor and the activity of the parasitoid was determined by the partial regression values (Table, 3), which emphasized highly significant positive relation between this factor and the parasitoid activity (P.reg was +2.94 ) and $t$ value was $(+3.57)$ for the $1^{\text {st }}$ year. While, this relation was insignificant positive (P.reg was +0.21$)$ and t value was $(+0.24)$ for the $2^{\text {nd }}$ one, when the mean dew point become around its mean. Also, the dew point was the most effective variable in population changes of the parasitoid $(26.10 \%)$ during the first year.

The obtained results revealed that, mean dew point entirely under the optimum range of total population of $A$. phoenicis activity in the $1^{\text {st }}$ year and within the optimum range in the $2^{\text {nd }}$ year.

The combined effect of the four factors (maximum temperature, minimum temperature, percentage of relative humidity and dew point) on the total population activity of parasitoid, $A$. phoenicis:

The C-multipliers method of partial regression was carried out to obtain the simultaneous effect of the four factors on the parasitoid activity. The estimated partial regression values indicated the presence of a simultaneous effect of these factors on the population of parasitoid in both years. During the 1st year, the combined effect of these climatic factors on the parasitoid population during the first year was highly significant where the «F» value, was 7.49. While, insignificant during the $2^{\text {nd }}$ one, where the $« F »$ value, was 2.63 . The influence of these combined climatic factors was expressed in Table 3 as percentages of explained variance which were 61.2 and $35.7 \%$ for $1^{\text {st }}$ and $2^{\text {nd }}$ years, respectively. The remaining unexplained variances are assumed to be due to the influences of other unconsidered and undetermined factors that were not included in this study in addition to the experimental error.

Data of both years concerning the effects of weather factors on the parasitoid population revealed clearly that the changeable weather factors which responsible for the most changes in $A$. phoenicis population. The dew point was the most effective variable in population changes of the parasitoid.

Generally, the most of the changes in the population of parasitoid are due to dew point $(26.10 \%)$, followed by minimum temperature $(11.30 \%)$ during the first year. While, the maximum temperature was the most effective variable in population change $(10.95 \%)$ during the second year.

\section{References}

1. El-Said MI (2000) Survey of date palm insects in North Sinai with special reference to the ecology and biology of the species, Parlatoria blanchardii (Targ.-Tozz), supper family Coccoidea, p. 97.

2. El-Sherif SI, Elwan EA, Abd-El-Razik MIE (2001) Ecological observations on the date palm parlatoria scale, Parlatoria blanchardii (Targioni- Tozzettii) (Homoptera diaspididae) in north Sinai, Egypt. Second International Conference on Date Palms.

3. Blumberg D (2008) Date Palm Arthropod Pests and Their Management in Israel. Phytoparasitica 36(5): 411-448.

4. Abd-Rabou S (1997a) Parasitoids attacking some species of scale insects (Homoptera: Coccoidea: Diaspididae) in Egypt. Proceeding of the First Scientific Conference of Agricultural Science 2: 727-736.

5. Abd-Rabou S, Hendaway AS (2000) Parastioids attacking date palm scale, Paralatoria balnchardii (Targ.) (Homoptera: Diaspididae) in Egypt. J Agric Sci Mansoura Univ 25(12): 8217-8222. 
6. Mourad AK, J Zanuncio (1998) Population dynamics of the date scale insect Parlatoria blanchardii (Homoptera: Diaspididae) on two datepalm varieties". $50^{\text {th }}$ International Conference of Crop Protection, $5^{\text {th }}$ May, Belgium, Gent, Europe, 63(2a): 389-395.

7. Orphanides GM (1982) Biology of the California red Scale, Aonidiella aurantii (Maskell) (Homoptera, Diaspididae), and its seasonal availability for parasitization by Aphytis spp. Boll Labor Entomol, Agraria Filippo Silvestri, 39: 203-212.

8. Fisher RA (1950) Statistical methods for research workers. (12 ${ }^{\text {th }}$ edn), Oliver and Boyd Ltd., Edinburgh, London, UK, pp. 518.

9. MSTATC (1980) A Microcomputer Program of the Design Management and Analysis of Agronomic Research Experiments. Michigan State Univ, USA
10. Abdel-Kareim AI, Awadalla SS (1998) Population dynamics of the date palm scale Parlatoria blanchardii (Targioni- Tozzetti) (Homoptera: Diaspididae). J Agric Sci Mansoura Univ 23(7): 3431-3441.

11. Gomaa AA (1980) Studies on palm trees insects belonging to Superfamily. Al-Azhar Univ, Cairo.

12. Saad AGA (1980) Studies on palm trees insects belonging to Coccoidea in Egypt. Al-Azhar Univ, Cairo, Egypt.

13. Eraki MM (1998) Ecological studies on some scale insects infesting date palm trees. Al-Azhar Univ, Egypt, pp. 127.

\begin{tabular}{|l|}
\hline \multicolumn{1}{|c|}{ Your next submission with JuniperPublishers } \\
will reach you the below assets \\
- Quality Editorial service \\
- Swift Peer Review \\
- Reprints availability \\
- E-prints Service \\
- Manuscript Podcast for convenient understanding \\
- Global attainment for your research \\
- Manuscript accessibility in different formats \\
( Pdf, E-pub, Full Text, audio) \\
- Unceasing customer service \\
Track the below URL for one-step submission \\
https://juniperpublishers.com/online-submission.php
\end{tabular}

